\title{
ANALISIS KESULITAN GURU BAHASA INDONESIA DALAM PENERAPAN PEMBELAJARAN HIGHER ORDER THINKING SKILLS (HOTS) DI SMK SWASTA PARIWISATA PRIMA SIDIKALANG
}

\author{
POSMA \\ posmasianturi003gmail.com \\ Universitas Katolik Santo Thomas Medan
}

\begin{abstract}
Abstrak. Penelitian ini bertujuan untuk mengetahui Analisis Kesulitan Guru Bahasa Indonesia dalam Pembelajaran Higher Order Thinking Skill (HOTS) di SMK Swasta Pariwisata Prima Sidikalang. Permasalahan kesulitan belajar dalam pembelajaran HOTS tersebut dideskripsikan berdasarkan dua aspek yang meliputi faktor kesulitan guru dilihat dari inteligensi dan faktor kesulitan guru dilihat dari non-inteligensi guru dalam pembelajaran bahasa Indonesia. Populasi dari penelitian ini adalah guru dan siswa di SMK Swasta Pariwisata Prima Sidikalang yang menerapkan pembelajaran berbasis HOTS. Hasil penelitian menunjukkan bahwa informan belum siap atau kesulitan dalam menerapkan pembelajaran berbasis HOTS. Pada aspek pelaksanaan pembelajaran, guru masih belum memahami secara keseluruhan mengenai tentang K13 sehingga membuat informan masih kesulitan dalam menentukan model pembelajaran yang digunakan dalam pembelajaran yang dibawakan. Guru juga masih kesulitan dalam penyusunan baik dalam KI, KD, penyusunan silabus, penyusunan RPP yang sesuai dengan kurikulum 2013. Hasil penelitian yang dilakukan peneliti juga menunjukkan bahwa pembelajaran berbasis HOTS masih belum dipahami baik dalam pembelajaran HOTS, penyusunan RPP yang berorientasi HOTS, penyusunan soal atau pertanyaan berbasis HOTS maupun dalam format penilaian dalam pembelajaran yang berbasis HOTS.
\end{abstract}

Kata Kunci: Kesulitan Guru, Pembelajaran Berbasis HOTS, Pendidikan Bahasa Indonesia.

Abstract. This study aims to determine the Analysis of the Difficulties of Indonesian Language Teachers in Learning Higher Order Thinking Skills (HOTS) at Prima Sidikalang Tourism Private Vocational School. The problem of learning difficulties in HOTS learning is described based on two aspects which include teacher difficulty factors seen from intelligence and teacher difficulty factors seen from teacher nonintelligence in Indonesian language learning. The population of this study were teachers and students at the Prima Sidikalang Tourism Private Vocational School who implemented HOTS-based learning. The results showed, informants were not ready or had difficulty implementing HOTS-based learning. In the aspect of implementing learning, the teacher still does not fully understand about K13 so that it makes informants still have difficulty in determining the learning model used in the learning that is delivered. The results of research conducted by researchers also show that HOTS-based learning is still not well understood in HOTS learning, HOTSoriented lesson plans preparation, preparation of questions or HOTS-based questions or in an assessment format in HOTS-based learning.

Keywords: Teacher Difficulties, HOTS-Based Learning, Indonesian Language Education

\section{PENDAHULUAN}

Dalam kurikulum 2013 revisi 2016, guru tidak lagi diposisikan sebagai orang yang serba tahu tentang materi yang akan diajarkannya, melainkan sebagai operator kurikulum yang memiliki tugas untuk membaca, memahami, menafsirkan, dan menjabarkan isi dan nilai yang terkandung dalam kurikulum, kemudian mentransfer nilai dan isi tersebut kepada peserta didik 


\section{POSMA \\ ANALISIS KESULITAN GURU BAHASA INDONESIA DALAM PENERAPAN PEMBELAJARAN HIGHER ORDER THINKING SKILLS (HOTS) DI SMK SWASTA PARIWISATA PRIMA SIDIKALANG}

melalui proses yang disebut pembelajaran. Pendidikan karakter dalam kurikulum 2013 bertujuan untuk meningkatkan mutu proses dan hasil pendidikan, yang mengarah pada pembentukan budi pekerti dan akhlak mulia peserta didik secara utuh, terpadu, dan seimbang, sesuai dengan standar kompetensi lulusan pada setiap satuan pendidikan.

Penerapan dalam HOTS masih sulit diterapkan guru dalam pembelajaran sehingga guru masih menciptakan soal yang hanya mengandalkan ingatan otak dibandingkan dengan berfikir secara kritis. Penerapan dalam penyusunan soal berbasis HOTS masih sangat minim untuk diterapkan dalam pembelajaran yang ada di sekolah. Sesuai dengan pernyataan, permasalahan yang muncul adalah cenderung berkaitan dengan masih banyak guru yang kebingungan dalam menerapkan pembelajaran berbasis HOTS tersebut. Para guru masih belum paham tentang penyusunan soal, sehingga mereka kesulitan tentang cara menerapkan dan menilai. Meskipun pemerintah sudah melakukan rangkaian berbagai kegiatan berupa pelatihan, seminar, dan sebagainya untuk implementasi kurikulum 2013 revisi 2016 yang benar. Masih banyak guru yang kebingungan dalam menerapkan pembelajaran berbasis HOTS dan penyusunan soal HOTS.

Guru adalah figur manusia sumber yang mencapai posisi dan memegang peran penting dalam pendidikan. Pendidik atau guru merupakan tenaga profesional yang bertugas melaksanakan proses pembelajaran, melakukan pembimbingan dan pelatihan, serta melakukan penelitian dan pengabdian kepada masyarakat, terutama bagi pendidik pada perguruan tinggi. Hal tersebut tidak disangkal karena lembaga pendidik formal adalah dunia kehidupan guru. Guru memegang peranan yang sangat strategis terutama dalam membentuk watak bangsa serta mengembangkan potensi-potensi siswa.

Kesulitan guru adalah adanya masalah karena guru tersebut merasa tidak puas dengan apa yang sedang terjadi dan dia memandangnya sebagai suatu yang perlu diprioritaskan (Hamalik, 2014: 1213). Kesulitan dalam proses pembelajaran dapat diartikan sebagai suatu kondisi dalam proses mengajar yang ditandai oleh adanya hambatan tertentu bagi seorang guru dalam kegiatan mengajarnya untuk memperoleh hasil yang ingin dicapai, hambatan itu mungkin disadari ataupun tidak disadari oleh seorang guru, baik bersifat psikologis, sosiologis atau fisiologis dalam proses mengajar (Asep, 2008: 7).
Berpikir adalah suatu proses simbolis (representasi mental) untuk memanipulasi informasi guna memecahkan masalah tertentu dan menghasilkan ide-ide kreatif. Berpikir merupakan suatu proses kompleks yang terjadi dengan mengonstruksikan skema-skema kognitif dan mengkategorikan setiap stimulus ke dalamnya. Berpikir juga disebut sebagai proses memecahkan masalah. Berpikir berfungsi untuk memecahkan masalah, mengambil keputusan dan menghasilkan ide-ide kreatif.

Taksonomi Bloom dianggap merupakan dasar bagi berpikir tingkat tinggi. Pemikiran ini didasarkan bahwa beberapa jenis pembelajaran memerlukan proses kognisi yang lebih daripada yang lain, tetapi memiliki manfaat yang lebih umum. Pada taksonomi Bloom, terdapat enam jenjang yang tersusun mulai dari kemampuan berpikir tingkat rendah (lower order thinking skill) menuju pada kemampuan berpikir tingkat tinggi (higher order thinking skill). Kemampuan berpikir tingkat rendah meliputi ranah pengetahuan, pemahaman, dan aplikasi/penerapan. Sedangkan kemampuan berpikir tingkat tinggi meliputi ranah menganalisis, mengevaluasi, dan mengkreasi.

Kemampuan berpikir tingkat tinggi (High Order Thinking Skill) merupakan proses berpikir yang tidak sekedar menghafal dan menyampaikan kembali informasi yang diketahui. Kemampuan berpikir tingkat tinggi merupakan kemampuan menghubungkan, memanipulasi, dan mentransformasi pengetahuan serta pengalaman yang sudah dimiliki untuk berpikir secara kritis dan kreatif dalam upaya menentukan keputusan dan memecahkan masalah pada situasi baru. Secara umum, terdapat beberapa aspek yang menunjukkan kemampuan berpikir tingkat tinggi yang dimiliki oleh seseorang yaitu kemampuan berpikir kritis, berpikir kreatif, serta memecahkan masalah.

Soal disusun berdasarkan kemampuan-kemampuan dasar dalam berfikir kritis. Guru dapat menyusun soal seperti pada contoh yang diperkenalkan oleh para peneliti, atau menyusun soal essay dengan bentuk tersendiri. Salah satu kemampuan dasar dalam berfikir kritis yang juga terkait dengan penyelesaian masalah (problem solving) adalah mencari solusi alternatif dengan memetakan jaringan permasalahan menggunakan peta pikiran (mind map) atau grafik organizer lainnya. Solusi permasalahan dapat dicari dengan 


\section{POSMA \\ ANALISIS KESULITAN GURU BAHASA INDONESIA DALAM PENERAPAN PEMBELAJARAN HIGHER ORDER THINKING SKILLS (HOTS) DI SMK SWASTA PARIWISATA PRIMA SIDIKALANG}

mengusulkan solusi alternatif dan dampaknya, kemudian memilih solusi yang saling efektif dan efisien.

Kesulitan guru dalam menerapkan pembelajaran HOTS merupakan masalah yang perlu dicari penyelesaiannya, sehingga program pembelajaran sesuai dengan standar kompetensi yang diterapkan. Permasalahan yang muncul adalah cara mengetahui dan memperoleh informasi tentang kesulitan guru dalam menyusun soal dalam bentuk HOTS. Materi ajar atau bahan ajar bahasa Indonesia secara umum harus disesuaikan pada setiap jenjang pendidikan. Tujuannya agar bahan ajar tersebut sesuai dengan kebutuhan siswa, guru, serta kurikulum yang ditentukan.

\section{METODE PENELITIAN}

Metode penelitian yang digunakan adalah metode penelitian deskriptif. Penelitian deskriptif adalah suatu bentuk penelitian yang paling dasar. Ditunjukkan untuk mendeskripsikan atau menggambarkan fenomena-fenomena yang ada, baik fenomena yang bersifat alamiah ataupun rekayasa manusia. (Nana Syaodih Sukmadinata, 2008: 72)

Dengan demikian jenis penelitian yang digunakan adalah kualitatif deskriptif (descriptive qualitative). Karena pendekatan kualitatif bersifat holistik (menyeluruh), akan dideskripsikan secara menyeluruh berupa kata-kata tertulis dari pernyataan tertulis maupun lisan dari guru-guru tentang bagaimana kesulitan guru Bahasa Indonesia dalam menerapkan pembelajaran HOTS sesuai kurikulum 2013 di SMA St. Petrus Medan. Subjek penelitian atau informan yang digunakan adalah guru. Guru yang menjadi sasaran utama untuk ditemukan datanya. Dalam hal ini sasaran lain adalah peneliti, siswa, guru lain, dan kepala sekolah. Ada 3 guru mata pelajaran Bahasa Indonesia di SMK Swasta Pariwisata Prima Sidikalang yang akan menjadi sasaran (subjek penelitian) utama untuk ditemukan datanya.

Teknik pengumpulan data disesuaikan dengan teknik atau tahapan (prosedur) pengumpulan data sesuai alat (instrumen) data yang digunakan. Teknik pengumpulan data yang digunakan adalah wawancara, dokumen, dan angket. Ada beberapa teknik analisis data dalam penelitian kualitatif adalah: (1) analisis interaktif, (2) analisis mengalir, (3) analisis domain, (4) analisis taksonomi, (5) analisis komponensial, dan (6) analisis tema.

\section{HASIL DAN PEMBAHASAN \\ 1. Hasil Penelitian}

Dari hasil wawancara ada 21 pertanyaan yang diajukan kepada setiap guru yang menjadi informan berkaitan dengan implementasi Kurikulum 2013 dan kesulitan guru Bahasa Indonesia dalam penerapan pembelajaran HOTS. Ada 3 informan yang diwawancarai. Berdasarkan hasil wawancara, ditemukan 10 jenis kesulitan yang dialami guru Bahasa Indonesia dalam penerapan pembelajaran HOTS, yaitu: 1)Penerapan model-model pembelajaran, 2)Peranan guru dalam pengembangan K13, 3)Strategi implementasi PPK dan pengembangan HOTS, 4)Bentuk, jenis dan teknik penilaian sesuai dengan K13, 5)Dalam hal memahamkan proses konsep pembelajaran berorientasi HOTS, 6)Perbedaan penyusunan RPP berorientasi HOTS dengan yang bukan HOTS dan penilaian dan evaluasi pembelajaran, 7)Menerapkan desain pembelajaran dalam bentuk pertanyaan dan peran guru dan peserta didik dalam proses pembelajaran HOTS, 8)Menerapkan model pembelajaran berorientasi pada keterampilan berpikir tingkat tinggi (HOTS) pada pembelajaran, 9)Format mengembangkan keterampilan berfikir tingkat tinggi (HOTS), 10)Implementasi penyusunan dan format kisi-kisi soal HOTS.

Dari hasil angket ada 14 komponen pertanyaan (186 jenis kesulitan) yang diuraikan pada angket yang diberikan kepada guru sebagai informan. Berdasarkan angket yang diberikan kepada 3 guru ditemukan data beberapa kesulitan yang dialami guru Bahasa Indonesia dalam penerapan pembelajaran HOTS. Dari 168 jenis kesulitan yang diuraikan, ditemukan ada 47 (27,9\%) jenis kesulitan yang dialami guru bahasa Indonesia dalam penerapan pembelajaran HOTS. Tidak ada informan (guru) yang menambahkan atau mengisi di luar jenis kesulitan yang diuraikan dari 14 komponen pertanyaan.

Analisis kesamaan jenis kesulitan yang dialami informan sesuai data temuan dari hasil wawancara dan hasil angket. Ada 10 jenis kesulitan yang ditemukan dari hasil wawancara dan 47 jenis kesulitan dari hasil angket. Untuk jenis kesulitan yang sama akan dibahas pada satu jenis kesulitan. Artinya, jenis kesulitan yang ditemukan baik dari hasil wawancara dan angket akan dipadukan, diurutkan, dan dianalisis. 
POSMA

ANALISIS KESULITAN GURU BAHASA INDONESIA DALAM

PENERAPAN PEMBELAJARAN HIGHER ORDER THINKING SKILLS

(HOTS) DI SMK SWASTA PARIWISATA PRIMA SIDIKALANG

\section{SIMPULAN}

Berdasarkan hasil analisis dan penelitian yang telah dilakukan, maka dapat disimpulkan bahwa:

1. Memahami Konsep Dasar K13 di SMK

2. Memahami Dokumen Kurikulum 2013 (K13) Mata Pelajaran Bahasa Indonesia di SMK

3. Memahami dan Mengembangkan Silabus Mata Pelajaran Bahasa Indonesia di SMK

4. Memahami Penyusunan Rencana Pelaksanaan Pembelajaran (RPP) Mata Pelajaran Bahasa Indonesia di SMK

5. Memahami dan Menerapkan Buku Teks Mata Pelajaran Bahasa Indonesia di SMK

6. Memahami Mengimplementasikan Kurikulum 2013 (K13) Mata Pelajaran Bahasa Indonesia SMK

7. Memahami dan Menerapkan Proses/Tahapan Pelaksanaan Pembelajaran sesuai K13 pada Mata Pelajaran Bahasa Indonesia

8. Memahami dan Menerapkan Model (Pendekatan/ Strategi/Metode) Pembelajaran sesuai Kurikulum 2013 (K13) pada Mata Pelajaran Bahasa Indonesia di

9. Jenis Kesulitan dalam Memahami dan Menerapkan Penilaian Pembelajaran sesuai Kurikulum 2013 (K13) pada Mata Pelajaran Bahasa Indonesia di SMK

10.Jenis Kesulitan dalam Memahami Konsep Pembelajaran Berorientasi HOTS pada Mata Pelajaran Bahasa Indonesia di

11.Jenis Kesulitan dalam memahami Penyusunan RPP berorientasi HOTS pada Mata Pelajaran Bahasa Indonesia SMK

12.Jenis kesulitan dalam memahami dan menerapkan Desain Pembelajaran Berorientasi pada Keterampilan Berpikir Tingkat Tinggi pada Mata Pelajaran Bahasa Indonesia di

13.Memahami dan menerapkan Modelmodel Pembelajaran Berorientasi pada Keterampilan Berpikir Tingkat Tinggi (HOTS) pada Mata Pelajaran Bahasa Indonesia di SMK

14. Memahami dan menerapkan Konsep dan Penyusunan Soal HOTS pada Mata Pelajaran Bahasa Indonesia di SMK
Tangerang: Tira Smart.

Arikunto dan Suharsimi, 2017.Prosedur Penelitian. Jakarta: Renika Cipta.

Emzir. 2010. Metodologi Penelitian Kualitatif: Analisis Data. Jakarta: Rajawali Pers.

Moleong, Lexy J. (2017).Metode Penelitian Kualitatif, cetakan ke-36, Bandung: PT. Remaja Rosdakarya Offset.

Mulyasa, 2016. Pengembangan dan Implementasi Kurikulum 2013.Bandung: PT Remaja

Rosdakarya.

Puspita.2014. Kesulitan Guru dalam Melaksanakan Pembelajaran K13.

Retnawati. 2015. Kurikulum 2013 Masalah dalam Pelaksanaan Kurikulum 2013.

Sugiyono. 2013. Metode Penelitian Kombinasi(Mixed Methods). Bandung: Alfabeta.

\section{DAFTAR PUSTAKA}

Abdullah Sani, Ridwan, 2019. Pembelajaran Berbasis Higher Order Thinking Skills (HOTS), 